\title{
Financial review as an element of corporate governance in the Polish legal regulations
}

\author{
Piotr Bartkowiak \\ Poznań University of Economics \\ Poland \\ e-mail:p.bartkowiak@ue.poznan.pl
}

\author{
Marcin Borkowski \\ Poznań University of Economics \\ Poland
}

\begin{abstract}
The aim of the current paper is to present financial review as an element of an efficiently working corporate governance system. The study was prepared on the basis of both the details of the legislation in force in Poland, as well as on the basis of International Accounting Standards. Moreover, the analysis will attempt at describing the roles of an expert auditor and a financial statement perceived as a basic tool of communication with stakeholders ${ }^{1}$ as well as will try to present the changes that have taken place within this area.
\end{abstract}

Received:

June, 2014

1st Revision:

October, 2014

Accepted:

November, 2014

DOI:

$10.14254 / 2071-$ $8330.2014 / 7-2 / 6$

Key words: financial statement, financial review, corporate governance

JEL Code: G34

\section{INTRODUCTION}

Inclusion of a financial review, both on an entity basis (expert auditor) as well as a functional basis (the process of reviewing) into the corporate governance can be substantiated by the classic contract theory. According to its tenets, a financial review is one of the tools designed to monitor people who run a company. In managing practice the role of a financial review is often overlooked because in majority of cases the process of reviewing as well as the opinion and the supplementing report issued on its basis are considered to be a mere obligation under the rules of corporate governance that is actually barely utilized for assessing effectiveness of corporate governance.

1 Due to the 01 January 2013 introduction of regulations changing the Accounting Act in accordance with the Act from 19 August 2011 concerning reduction of certain duties of citizens and entrepeneurs (Journal of Laws, No 232, item 1378), the obligation of publishing statements in the Official Gazette of the Republic of Poland B (Monitor Polski B) has been waived, leaving only the requirement of submitting an entry to the court register. Information about an entry to the National Court Register about submitting a statement is automatically published in the Court and Commercial Gazette (Monitor Sądowy i Gospodarczy). 


\section{FINANCIAL STATEMENT REVIEW (AUDIT)}

Auditing financial statements, apart from corporate governance, is the main factor contributing to financial stability by means of an objective presentation of a company's financial condition. "Credibility of a financial statement audit is key for restoring confidence and trust in the market. It helps to protect investors and reduces the costs of capital on the part of companies" (Polityka badania sprawozdań finansowych).

\subsection{Obligation of review}

A drawn up financial statement is subject to an audit carried out by an independent expert auditor. The subjective scope of entities that should be reviewed has been specified in chapter 7 of the Accounting Act, which states in Art. 64, Section 1 that the following elements are subject to review: annual consolidated financial statements of corporate groups, annual financial statements of institutions that continue their activity, such as banks, insurance companies, reinsurance companies, savings and credit unions, entities operating under the regulations on trading in securities and regulations on investment funds, entities operating under the regulations on organizations, pension funds and joint stock companies, excluding companies that are within the organization on the balance sheet day (Dz. U. 2013, item. 330).

Moreover, an audit should be carried out in entities which in the previous trading year, for which a financial statement was made, met at least two of the following boundary conditions:

a) an average annual employment measured in full-time jobs was at least 50 people,

b) total assets at the end of the trading year was a PLN equivalent of at least EUR 2500 000,

c) net income of sales of goods and producst as well as financial operations for the trading year was a PLN equivalent of at least EUR 5000000.

Further entities whose financial statements are subject to an audit are acquiring companies and newly established companies financial statements of which are drawn up for the trading year in which the acquisition took place. The annual financial statements of the entities are carried out in accordance with the International Accounting Standards. Subject to the audit are also consolidated financial statements of investment funds with separate subfunds as well as individual annual statements of subfunds. Other entities preparing annual financial statements can have them audited on a voluntary basis. In domestic environment the number of audited financial statements in years 2010-2012 has been presented in Figure 1.

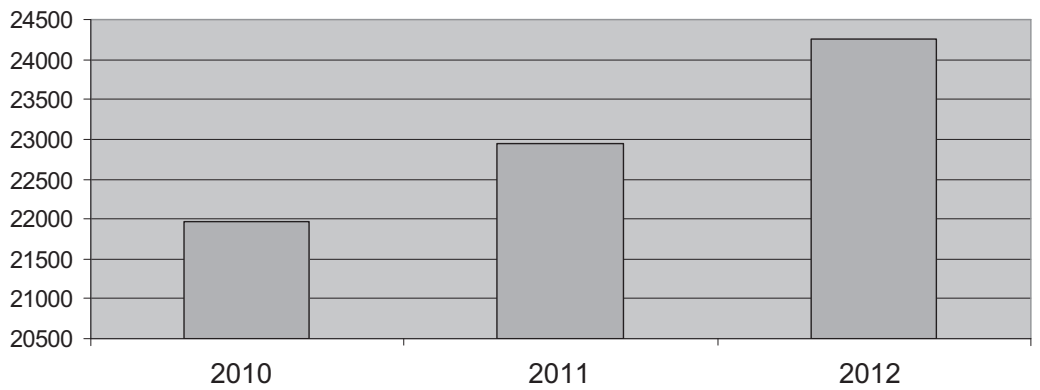

Figure 1. Number of financial statement audits carried out by expert auditors.

Source: A. Pokojska, Bez Monitora B taniej. Ale są też i minusy, Gazeta Prawna 2013, no. 177. 


\subsection{Purposes of a financial statement review (audit)}

A financial statement audit is fundamental for the quality of the information included in a financial statement. According to the Art. 65 of the Accounting Act, the basic purpose of a financial statement audit is to provide a written opinion on whether the statement is in line with the applicable accounting regulations (policy) and whether it correctly and clearly shows the financial and economic standing of the audited entity as well as its financial result (Dz. U. 2013, item. 330).

According to the Resolution no. 1608/38/2010 of the National Chamber of Statutory Auditors from 16 February 2010 on national financial review standards (www.kibr.bip.waw.pl) in Poland, what applies to annual financial statements is the national financial audit standard no. 1, that is, "General regulations of financial statement audits" (Resolution No. 1608/38/2010).

A financial statement audit is designed to obtain evidence that allows to determine with a sufficient degree of certainty that the accounting books along with the accounting evidence that constitute the basis of the records entered to them, as well as financial statements drawn up on this basis, comply in all important aspects with the requirements specified in the Accounting Act ${ }^{2}$.

The necessity of auditing financial statements stems from:

the increasingly complicated economic operations, which generates a potential danger connected with their incorrect registering in accounting books;

the increasing need for accurate information about the financial and economic situation of companies as well as financial results achieved by them.

Verifying correctness of account records and information included in the financial statement allows to check if economic events have been correctly registered. ${ }^{3}$ The process of verification confirms credibility of the drawn up document, thus, it contributes to the correctness of the information that it includes. As a result, the verification process minimizes information asymmetry and ensures its credibility.

A financial statement audit is a way of reassuring the owners that the entity is correctly and legally operating and helps them assess the legitimacy ${ }^{4}$ of its activities. A financial statement audit is also a basis for assessing the efficiency of the executive body's operations and functioning of regulatory authorities as well as of evaluating cost efficiency ${ }^{5}$ and feasibility ${ }^{6}$ of the company.

\subsection{Financial statement review and audit}

The term "financial statement audit" is understood as an attempt of determining if the information included in the financial report, that constitiutes the basis for preparing accounting books, is correct and in line with the assumed assessment criteria.

The term "review" denotes an internal inspection that constitutes, among other things, in "verification, assessment and inspection of correctness and effectiveness of operations carried out by accounting systems and internal inspections" (www.ifac.org). A review comprises not only the audit itself but also suggestions of corrections to the information included in the audit as well as an opinion about the audit's credibility along with a supplementing report.

2 They are correct and the statement is credible and it clearly presents the financial, economical standing as well as financial result.

3 Data coming from financial statements could include errors or even could be intentionally distorted.

4 That is, the accounting system's compliance with the provisions of the Act as well as other regulations.

Appropriate relation between costs and effects or if the extent of occurred damages has been limited.

${ }^{6}$ Determine if the best means have been used to achieve the identified goals or causes of the failure in case they have not been achieved. 
Financial statement review is described as a systemic investigation that is supposed to:

objectively determine the credibility of data that describes business activity and the financial as well as economic standing of the audited company, and which is included in the financial statement and constitutes the basis for its drawing up in the accounting books;

establish the compatibility level;

provide the results of the study to the interested users of the financial statement in the form of an opinion and a supplementing report.

\subsection{Functions of a financial statement review (audit)}

A financial statement audit is designed to check the correctness, credibility and clarity of information presented in the financial statement. This is a primary function in contrast to the functions of a review, which are as follows:

informative function (the expert auditor gives the information by means of an opinion along with a report or other documents),

verification (the expert auditor states if the financial statement is correct or specifies what errors it contains).

Bearing in mind that a financial statement audit is a crucial part of a review, the controlling function is also a function of the review. On the other hand, verification and informative functions are not functions of an audit but are connected with the review. Only after including suggested corrections in the statements does an audit acquire an informative function as well. Therefore, the review should be considered as serving a corrective function as well, which has been described in Graph 1.

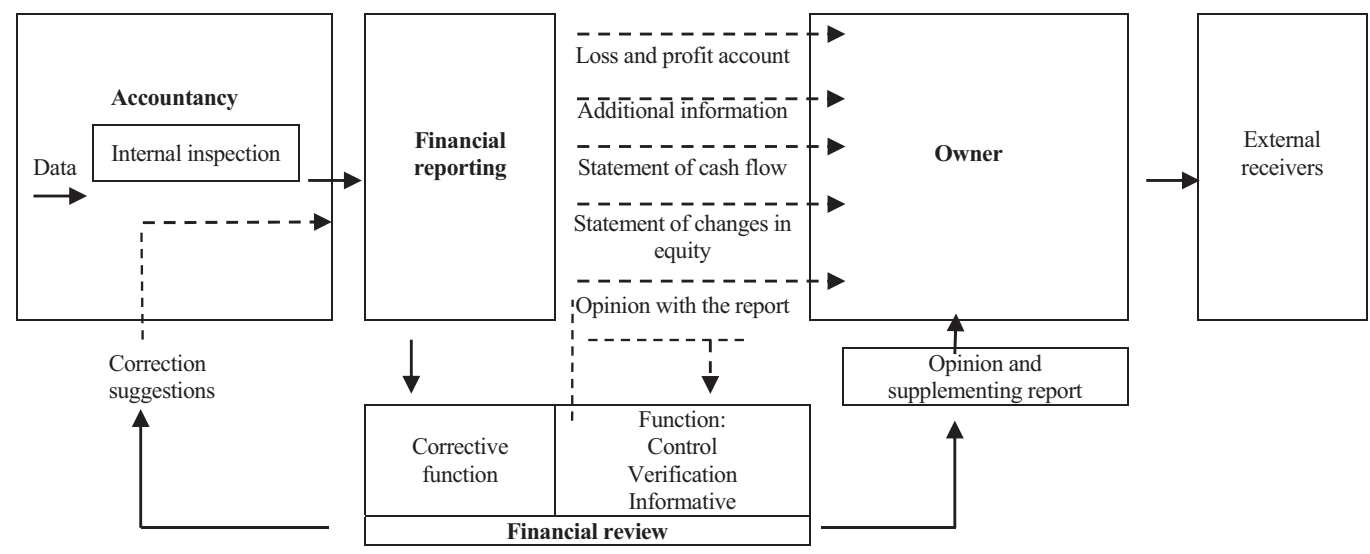

Graph 1. Corrective function in the system of financial statement reviews

Source: Andrzejewski, M., 2011, System rewizji finansowej z uwzględnieniem funkcji korygujacej sprawozdanie finansowe, Theoretical Journal of Accounting, Vol. 62 (118), The Accountants Association in Poland, Warszawa, p. 31.

From the perspective of the capital market it is very important that the financial statement audit has both informative and verification functions. Reliable and trustworthy information has a big gravity because 
current share prices are determined by estimations of future incomes ${ }^{7}$. The more complete and credible the information is, the smaller the risk of incorrect estimation of future cash flows. "If there is uncertainty regarding completeness and credibility of company data, fair value measurement becomes difficult, whereas share price range becomes relatively broad" (Rawicki 2012, p. 49).

Research by Ch. Botosan and M. Plumlee has shown that "only publication of annual reports is negatively correlated with the cost of capital. Other forms, that is, daily investor relations and quarterly financial statements lead to a higher cost of capital due to the volatility they generate" (Rawicki 2012, p. 49). However, it should be pointed out that this research concerned a developed capital market. Still, the basic source of financial resources in Poland is the banking system, thus, this factor is not so important for investors but it is rather an element of shareholder supervision.

During the crisis of 2007 and 2008 financial review became more significant. Moreover, the issue of how functionality of a financial statement review should be improved acquired new importance. European Committee suggested that the expert auditor's opinon shall be extended by the following elements:

1) "data allowing to set the significance threshold,

2) information about the risks of significant distortions,

3) statement on the entity's standing and the possibility of continuation of its activity" (Schruff 2013, pp. $21,22)$.

\section{Financial review as a monitoring tool}

Theoretically, the process of review allows monitoring financial information provided by the management to other shareholders, while the auditor's independence is a guarantee of his work's credibility. In practice, the wave of corporate scandals of the previous decade was a reason why more attention is now paid to activities of managers as well as auditors.

It is assumed in the literature that the matter of financial review is explained by contract theory ${ }^{8}$. "According to this theory, organization is a set of contracts among many economic agents. By concluding a contract, an agent becomes obliged to provide the organization with resources and expects to receive remuneration for the resources that he contributes." (Dobija 2011, p. 25). Accounting theory allows to control the flow of resources within an organization, with the accounting system itself being designed to provide clear information about the company.

In order to prevent exploitation of the resources by the management, certain mechanisms have been implemented to control and monitor managers' activities. (Jensen, Meckling 1976). "An auditor is supposed to check if managers correctly fullfil their duty of accounting for their activity and usage of resources given to them" (Dobija 2011, p. 27). Thus, expert auditor's activity is meant to limit agency costs, that is, a loss of organization's value resulting from its members' selfish behavior'. This is also why it is understood that financial review is an element of supervision of managers' behavior, thus, it constitutes an internal tool of corporate governance.

\footnotetext{
Fair share value is based on credible assumptions regarding future cash flows.

8 Another theory explaining the significance of financial review is the behavioral theory. It does not perceive the review as a neutral and technical actvity but it presumes that auditors deal not only with application of certainty generation methods, but are also concerned with maintaining their position and authority as a priviledged source of knowledge.

9 However, it should be mentioned that an expert auditor, according to the contract theory is also a "specific" agent, which gives rise to the issue of "dual agency".
} 


\section{THE ROLE OF AUDITORS AND FINANCIAL STATEMENTS IN CORPORATE GOVERNANCE}

In early economic organizations, the audit process was conducted by individuals appointed from among administrators and shareholders ${ }^{10}$. In the 15 th century, the time of the great trading companies, the regulations associated with auditing ${ }^{11}$ contained the statutes of the companies ${ }^{12}$. Initially, the main responsibility of the persons appointed to perform an audit was to verify cash transactions and documents confirming the purchases made to the benefit of the company. Auditors were also appointed for the examination of reported irregularities appearing on the private capital accounts of shareholders ${ }^{13}$. With time, the practice of appointing auditors by investors disappeared and became a prerogative of the administrators.

\subsection{The institution of an expert auditor}

The employment of independent expert auditors, performing monitoring on behalf of owners and administrators, did not become popular until the second half of the 19th century. The year 1862 is considered to be the date of birth of the expert auditor as a profession. The British Companies Act, issued in this year to ensure detailed financial reporting and prevent fraud, organized and standardized the accounting system. In accordance with its principles, audits of accounting records started to be performed, and the auditors selected from among shareholders were gradually replaced by professional auditors, which resulted from the introduction of administrators' liability.

The profession of an auditor continued to form until 1933, when the acts introducing the 'New Deal' to the USA sanctioned the necessity for audits to be conducted by independent and certified auditors. Auditors, i.e. professional and independent experts confirming the credibility of financial statements, became the individuals ensuring the proper functioning of the capital market.

In Anglo-Saxon countries, the persons performing financial statement examinations are referred to as: in the USA - Certified Public Accountant, in the UK - Chartered Accountant. In continental Europe, the terms used to describe auditors include: in Germany - Wirtschaftsprïfer (economic examiner-verifier), in France I'expert comptable (expert accountant).

In Poland the profession of an expert auditor is sanctioned by the Stock Corporation Act ${ }^{14}$. Expert auditors were authorized to perform annual reviews of balance sheets, profit and loss statements, and company management reports. They were appointed by registry courts, from lists presented by the chambers of commerce and industry ${ }^{15}$. These regulations were taken over by the Commercial Code of 1934, but the issues associated with performing the work of an expert auditor were not regulated by any unified legal rules. The institution of a 'certified expert accountant' was not created until 1960. When adjusting the functioning of auditors to the market conditions after 1989, in accordance with the act of October 19, 1991 on auditing

10 In medieval Europe, each guild was required to conduct annual audits, which were carried out by the members of that guild.

11 Originally, auditing was aimed at verifying the authenticity and reliability of issued documents (invoices). It was associated with the fact that all economic transactions were conducted by shareholders on behalf of the Company. Purchases were financed by the shareholders and, later on, reimbursed from the funds of the East India Company on condition that an audit was performed.

12 In 1621, a new statute was published, which contained detailed rules for bookkeeping within a company and for appointing auditors from among its administrators (Auditors in the Court of Committees) and shareholders (Auditors in the General Court).

13 First professional auditors appeared in the British East India Company.

14 Ordinance of the Polish President of March 26, 1928.

15 Ordinance of the Polish Minister of Trade and Industry of December 12, 1928. 
and publishing financial statements and certified auditors and their self-government (Dz.U. No 111, item 480), the term 'independent exper auditor' was introduced. (Dz. U. 2009, No. 77, item. 649) In the circumstances specified by the Accounting Act, only expert auditors are authorized to review (audit) financial statements in Poland.

\subsection{Financial reporting and its function in corporate governance}

Research results confirm that a good corporate governance system is correlated with the quality of financial reporting and reduces the number of financial irregularities (Abbott and Parker 2000, Farber 2005) and financial corrections (Abott in. 2004) as well as the level of profit management (Bedard and Johnstone 2004). A repeated study (Cohen et al. 2008), performed after the implementation of the SOX Act, pointed to a significant increase in the effectiveness of the corporate governance system and a substantially more positive assessment of the audit committee members as possessing adequate knowledge and performing their function properly.

In domestic conditions, the final effect of a financial statement audit performed by an expert auditor is a written opinion and a supplementary report. When an expert states that a financial statement is reliable and clear to a 'reasonable' degree and that it is in line with the applicable framework of financial reporting, it means that the financial statement in its entirety does not contain any significant irregularities resulting from fraud or error ${ }^{16}$.

An opinion ${ }^{17}$ from a financial statement review presents the position of an expert auditor with regard to the appropriateness of bookkeeping, the statement's compliance with the rules of accounting, and the conformity of the statements's form and content to the applicable legislation. It also contains information on whether the financial statement accurately and clearly presents all information relevant for the assessment of a given unit.

Additionally, in his or her opinion, the expert auditor points to all threats to the continuation of the unit's economic activity which were revealed during the review. The auditor provides one of the four following opinions about the reviewed financial statement:

1) unqualified opinion,

2) unqualified opinion with explanatory notes,

3) qualified opinion,

4) adverse opinion.

An expert auditor may also issue a disclaimer of opinion concerning the reviewed financial statement. Such a situation may occur only when there exist circumstances that prevent the formulation of an opinion.

\section{FINANCIAL STATEMENT AS AN INFORMATION PRODUCT}

A financial statement, together with an opinion of an expert auditor and a decision of an endorsing authority on the approval of the statement and division of profits or loss coverage, is submitted to an appropriate court register. The submission of a statement to an appropriate court register, as well as publishing and making it available, are regulated by art. 69, par. 1 of the Accounting Act.

16 It has to be remembered that an external auditor provides an opinion concerning the reliability of a financial statement, not the economic achievements or the quality of the financial statement of a unit in comparison to other units.

17 A report of an expert auditor from a financial statement review constitutes a detailed justification for the issued opinion. 
The head of a unit submits the following documents to the correct court register, based on the location of the unit: annual financial statement, opinion of an expert auditor ${ }^{18}$, copy of a resolution or decision of an endorsing authority on the approval of the annual financial statement and division of profits or loss coverage, and a report on operations for the units for which the report was obligatory - within 15 days from the date of approval of the annual financial statement.

The above-mentioned regulations result from the provisions of art. 4 of the Act of August 19, 2011 on the Reduction of Certain Obligations of Citizens and Businesses (Dz. U. 2011, No. 232, item. 1378). The comparison of the changes associated with making reports available is presented in Table 1.

Table 1

Comparison of the changes associated with publishing reports and making them available

\begin{tabular}{|l|l|}
\hline \multicolumn{1}{|c|}{ Art. 69 par. 1 - change } \\
\hline \multicolumn{1}{|c|}{ Before the change } & \multicolumn{1}{|c|}{ After the change } \\
\hline $\begin{array}{l}\text { The head of the unit submits the following documents to } \\
\text { an appropriate court register: annual financial statement, } \\
\text { opinion of an expert auditor, if it was reviewed, subject to } \\
\text { par. 1a, copy of a resolution or decision of an endorsing } \\
\text { authority on the approval of the annual financial state- } \\
\text { ment and division of profits or loss coverage, and, in the } \\
\text { case of units referred to in art. } 49 \text { par. 1, also a report on } \\
\text { operations, within 15 days from the date of approval of the } \\
\text { annual financial statement. }\end{array}$ & $\begin{array}{l}\text { The head of the unit submits the following documents to } \\
\text { a resolution or decision of an endorsing authority on the } \\
\text { approval of the annual financial statement and division of } \\
\text { profits or loss coverage, and, in the case of units referred to } \\
\text { in art. 49 par. 1, also a report on operations, within 15 days } \\
\text { from the date of approval of the annual financial statement. }\end{array}$ \\
\hline \multicolumn{2}{|c|}{ Art. 69 par. 1b - change } \\
\hline $\begin{array}{l}\text { The head of an office of a foreign entrepreneur submits an } \\
\text { annual financial statement of the office in an appropriate } \\
\text { court register. In the case of offices of credit or financial } \\
\text { institutions, also the following documents, translated into } \\
\text { Polish by a sworn translator, have to be submitted: } \\
- \text { annual financial statement of the credit or financial } \\
\text { institution; } \\
- \text { copy of a resolution or decision of an endorsing authority } \\
\text { on the approval of the annual financial statement of the } \\
\text { credit or financial institution; } \\
- \text { copy of a resolution or decision of an endorsing author- } \\
\text { ity of the credit or financial institution on the division of } \\
\text { profits or loss coverage. }\end{array}$ & $\begin{array}{l}\text { The head of an office of a foreign entrepreneur submits an } \\
\text { court register. }\end{array}$ \\
\hline
\end{tabular}

18 If it was reviewed 


\begin{tabular}{|c|c|}
\hline \multicolumn{2}{|c|}{ Art. 70 par. 1 - change } \\
\hline $\begin{array}{l}\text { The head of a unit, referred to in art. } 64 \text { par. 1, is obliged to } \\
\text { submit an introduction to the financial statement, constitut- } \\
\text { ing a part of additional information, a balance sheet, an } \\
\text { income statement, a statement of changes in equity, and } \\
\text { a cash flow statement for the financial year, to be published } \\
\text { within } 15 \text { days from the date of their approval, together } \\
\text { with an opinion of an expert auditor, subject to par. 1c, and } \\
\text { a copy of a resolution or decision of an endorsing authority } \\
\text { on the approval of the financial statement and division } \\
\text { of profits or loss coverage. The scope of the annual and } \\
\text { semi-annual financial statements of investment funds, } \\
\text { including combined financial statements of investment } \\
\text { funds with dedicated subfunds and non-consolidated state- } \\
\text { ments of subfunds, as well as the deadline for submission } \\
\text { to publication of the annual financial statement, including } \\
\text { combined financial statements of investment funds with } \\
\text { dedicated subfunds and non-consolidated statements of } \\
\text { subfunds, are defined by separate regulations. }\end{array}$ & $\begin{array}{l}\text { The head of a unit, referred to in art. 64, to which art. } 69 \text { is } \\
\text { not applicable, is obliged to submit an introduction to the } \\
\text { financial statement, constituting a part of additional infor- } \\
\text { mation, a balance sheet, an income statement, a statement } \\
\text { of changes in equity (of the fund), and a cash flow state- } \\
\text { ment for the financial year, to be published within } 15 \text { days } \\
\text { from the date of their approval, together with an opinion } \\
\text { of an expert auditor and a copy of a resolution or decision } \\
\text { of an endorsing authority on the approval of the financial } \\
\text { statement and division of profits or loss coverage. }\end{array}$ \\
\hline \multicolumn{2}{|c|}{ Art. 70 par. 2 - change } \\
\hline $\begin{array}{l}\text { The publication, referred to in par. 1-1d and art. } 64 \text { par. } \\
4 \text {, takes place in the Official Gazette of the Republic of } \\
\text { Poland, 'Monitor Polski B', and in the case of cooperatives } \\
\text { - in 'Monitor Spółdzielczy'. }\end{array}$ & $\begin{array}{l}\text { The publication, referred to in par. 1, takes place in } \\
\text { the 'Monitor Sądowy i Gospodarczy' national official } \\
\text { gazette, and in the case of cooperatives - in 'Monitor } \\
\text { Spółdzielczy'. }\end{array}$ \\
\hline
\end{tabular}

Source: Zmiany w ustawie o rachunkowości, Theoretical Journal of Accounting, No. 20 (308) 2011, p. 6.

The obligation to publish opinions and financial statements in 'Monitor Polski B' was abolished. Starting from January 1, 2013, financial statements are submitted only to the National Court Register and published in the 'Monitor Sądowy i Gospodarczy' national official gazette. Currently, there is not way to quickly check a potential counterparty. Access to financial statement is only possible from the reading room of a registry court appropriate to the registered office on an entrepreneur, on condition that the files are not being supplemented (Pokojska 2013).

The list of responsibilities associated with publishing reports and making them available according to the new regulations is presented in Table 2.

Table 2

Responsibilities associated with publishing reports and making them available

\begin{tabular}{|l|l|}
\hline \multicolumn{1}{|c|}{ Type of responsibility } & \multicolumn{1}{c|}{ Delivery date } \\
\hline \multicolumn{1}{|c|}{1} & \multicolumn{1}{c|}{2} \\
\hline $\begin{array}{l}\text { Submission of an annual financial statement, together } \\
\text { with other documents, to shareholders, stockholders, or } \\
\text { members }\end{array}$ & $\begin{array}{l}\text { Not less than 15 days before a meeting of shareholders, } \\
\text { general meeting of stockholders, or general meeting of } \\
\text { members (members' representatives), i.e. until June 15, } \\
2013\end{array}$ \\
\hline $\begin{array}{l}\text { Submission of an annual financial statement, together } \\
\text { with other documents, to the Internal Revenue Office by } \\
\text { a corporate income taxpayer }\end{array}$ & $\begin{array}{l}\text { Within 10 days from the date of approval of the statement, } \\
\text { i.e. not later than July 10, 2013 }\end{array}$ \\
\hline $\begin{array}{l}\text { Submission of an annual financial statement to the Internal } \\
\text { Revenue Office by a personal income taxpayer }\end{array}$ & Not later than April 30, 2013 \\
\hline
\end{tabular}




\begin{tabular}{|c|c|}
\hline 1 & 2 \\
\hline $\begin{array}{l}\text { Submission of an annual financial statement to the } \\
\text { National Court Register (NCR), together with other docu- } \\
\text { ments - this obligation only applies to the units subject to } \\
\text { NCR registration }\end{array}$ & $\begin{array}{l}\text { Within } 15 \text { days from the date of approval of the financial } \\
\text { statement for the financial year, i.e. not later than July } 15 \text {, } \\
2013\end{array}$ \\
\hline $\begin{array}{l}\text { If a financial statement was not approved in the time-peri- } \\
\text { od stated in art. } 53 \text { par. } 1 \text {, it needs to be submitted, together } \\
\text { with adequate documents, in the court register within } 15 \\
\text { days after this date (i.e. not later than July } 15,2013 \text { ) and } \\
15 \text { days after its approval }\end{array}$ & \\
\hline $\begin{array}{l}\text { Submission of a financial statement with other required } \\
\text { documents to be published in 'Monitor Sądowy i Gospo- } \\
\text { darczy'. This obligation only applies to the units that are } \\
\text { obliged to have their statements reviewed and which do } \\
\text { not submit their statements to the NCR }\end{array}$ & $\begin{array}{l}\text { Within } 15 \text { days from the date of approval of the financial } \\
\text { statement for the financial year, i.e. not later than July } 15 \text {, } \\
2013\end{array}$ \\
\hline $\begin{array}{l}\text { Submission of a cooperative financial statement with } \\
\text { other required documents to be published in 'Monitor } \\
\text { Spółdzielczy', if the annual financial statement is subject } \\
\text { to obligatory review }\end{array}$ & $\begin{array}{l}\text { Within } 15 \text { days from the date of approval of the financial } \\
\text { statement for the financial year, i.e. not later than July 15, } \\
2013\end{array}$ \\
\hline
\end{tabular}

Source: GOFIN, Obowiązi zwiazane z udostepnianiem sprawozdania za 2012, Theoretical Journal of Accounting, No. 7 (343) 2013, p. 5.

\section{THE RESPONSIBILITIES OF THE BODY MEMBERS OF THE UNITS COMPILING FINANCIAL STATEMENTS}

The act on expert auditors and their self-government, entities entitled to audit financial statements, and public supervision obliges public units (e.g. issuers of securities) to appoint a three-person task group within their supervisory boards, i.e. an audit committee.

Its main task is to monitor the financial reporting process and the efficiency of the systems for internal control, internal audit, and risk management.

Unit organs, persons (exper auditor), or other units (e.g. the audit committee, which is not a unit organ itself) are involved in the functioning of the accounting system to various degrees. The units responsible for the supervision of the accounting system are presented in Figure 2.

Inadequate execution of the responsibilities resulting from the objective scope of accounting and other regulations of the balance sheet law may consist in intentional ${ }^{19}$ or unintentional distortion of the image of the financial situation and achievements of a unit. The entirety of these actions may result from the so-called creative accounting oriented at misleading the user of financial statements, or from inadequate performance of legal obligations.

The obligation to make sure that a financial statement and report on operations meet the requirements of the Accounting Act was, in accordance with art. 4a paragraph 1 of this Act, entrusted to the head of a unit and the members of its supervisory board or other body supervising the unit which compiled the statement.

19 E.g. withholding information concerning a potential cessation of activity of a given entity or other risks for a unit. 


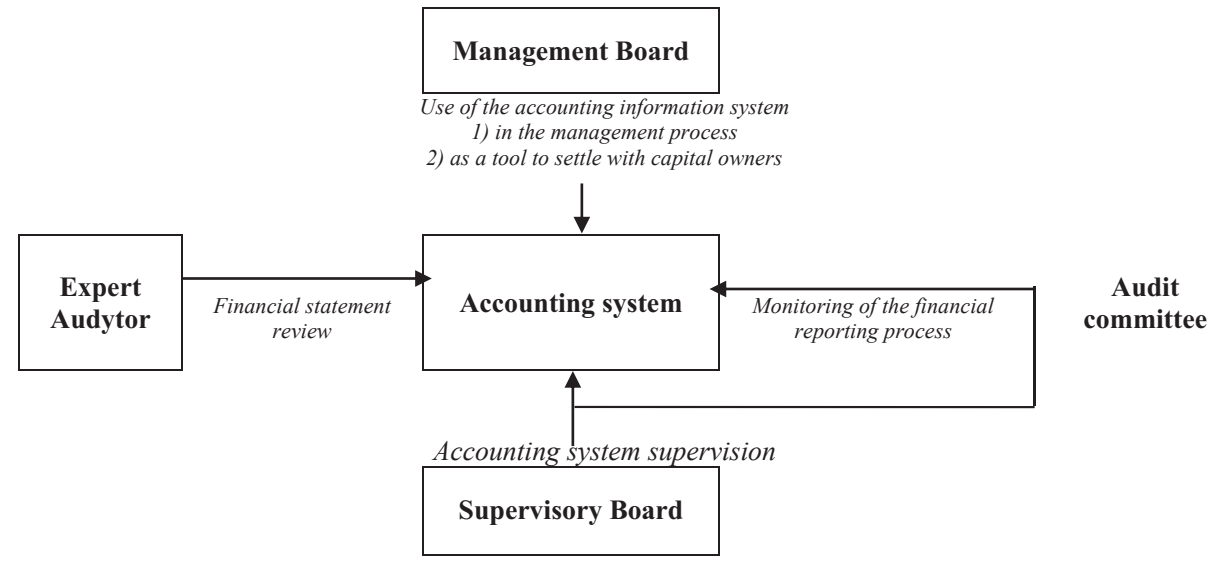

Figure 2. The units responsible for accounting system supervision

Source: Walińska, E., Gad, J., 2012, Odpowiedzialność rad nadzorczych za sprawozdania finansowe - doświadczenia polskich spótek publicznych, Theoretical Journal of Accounting, Vol. 66 (122), The Accountants Association in Poland, Warszawa, p. 208.

The provisions of this article result from the implementation of a directive $\mathrm{e}^{20}$ on the responsibilities and liabilities of a unit's body members associated with the compilation and publication of financial statements and 'reports on operations' of the unit, as well as joint and several liability for all losses resulting from the violation of these responsibilities.

The responsibility for the compliance of financial statements with the provisions of the Act lies, in the case of limited companies, with the members of the management board and supervisory board. Therefore, the members of both of these bodies should ensure the reliability of financial statements ${ }^{21}$.

The above-mentioned regulation 'seems to be especially difficult for supervisory board members, who perform two contradictory roles at the same time. One consists in objective supervision over all areas of the company's activity, (...) while the other, shared with the management board, boils down to the responsibility for the compliance of financial statements and reports on operations with the Accounting Act' (Walińska and Gad 2012). Article 4a was implemented 'directly' from the Anglo-Saxon, monistic corporate governance system (where a supervisory board is not present as a body of a company) to the dualistic Polish system. Therefore, it needs to be pointed out that, in view of art. 382 of the Commercial Companies Code, the responsibility of the supervisory board is of formal and legal nature, while in accordance with art. $4 \mathrm{a}$ of the Accounting Act, it is also of technical nature, as it is associated with ensuring the compliance of financial statements with the balance sheet law, which results in taking on the responsibility for the implemented accounting policy, which the management board is concerned with.

20 Directive 2006/46/EC of the European Parliament and of the Council of 14 June 2006 amending Council Directives $78 / 660 / \mathrm{EEC}$ on the annual accounts of certain types of companies, 83/349/EEC on consolidated accounts, 86/635/EEC on the annual accounts and consolidated accounts of banks and other financial institutions and 91/674/EEC on the annual accounts and consolidated accounts of insurance undertakings (O.J. EC No L, Edition 224, of August 16, 2006).

21 This responsibility also relates to report on operations, if obligatory. 


\section{CONCLUSION}

Financial auditing is not just a technical tool for the verification of the financial statements prepared by the management. It is also an important element of the corporate governance system, which exerts significant influence on the effectiveness of this system. The performance of a financial audit provides a sense of security to investors, who may potentially be exposed to being misled by inaccurate financial statements. The functioning of financial auditing provides such statements with reliability. It also enables the reduction of information asymmetry in corporate governance, especially when the economy is now global.

As a result of the reduction of reporting obligations, structural changes took place in the communicative role of a financial statement and expert's opinion in the contacts with stakeholders. The disappearance of 'Monitor Polski B' provided entrepreneurs with additional savings, but at the same time reduced the availability of external financial statements and of information on enterprises for stakeholders.

\section{REFERENCES:}

Abbot, L. J., Parker, S. (2000), Auditor selection and audit committee characteristic, Auditing: A Journal of Practice and Theory, Vol. 19, No 2, pp. 47-66.

Abbot, L. J., Parker, S., Peters, G. F. (2004), Audit committee characteristic and restatements, Auditing: A Journal of Practice and Theory, Vol. 23, No. 1, pp. 69-87.

Andrzejewski, M. (2011), System rewizji finansowej z uwzględnieniem funkcji korygujacej sprawozdanie finansowe, Theoretical Journal of Accounting, Vol. 62 (118), The Accountants Association in Poland, Warszawa, pp. 23-38.

Bedard, J. C., Johnstone, K. M. (2004), Earnings manipulation risk, corporate governance risk, and auditors planning and pricing decisions, Accounting Review, Vol. 79, No. 2, pp. 277-304.

Cohen, J.R., Krishnamoorty, G., Wright, A.M. (2008), Corporate governance in the past Sarbanes - Oxley era, Contemporary Accounting Research, Vol. 27, No 2., pp. 751-786.

Dobija, D. (2011), Audyting jako element ladu korporacyjnego, Theoretical Journal of Accounting, Vol. 64 (120), The Accountants Association in Poland, Warszawa, pp. 25-37.

Farber, D. B. (2005), Restoring trust after fraud:Does corporate governance matter?, Accounting Review, Vol. 80, No. 2, pp. 539-561.

GOFIN, (2013), Obowiazki zwiazane z udostępnianiem sprawozdania finansowego za 2012 r., Theoretical Journal of Accounting, No. 7(343), p. 4.

Jensen, M.C., Meckling W.H. (1976), Theory of Firm: Managerial Behavior, Agency Costs and Ownership Structure, www. sfu.ca/ - wainwrig/Econ400/jensen-meckling.pdf (referred on 01/09/2014).

Pokojska, A. (2013), Bez Monitora B taniej. Ale sq też minusy, Dziennik Gazeta Prawna, No. 177.

Rawicki, T. (2012), Obniżenie kosztu kapitału przez relacje inwestorskie, Enterprise Science Quaterly, No. 2, pp. 48-53.

Resolution No. 1608/38/2010 Krajowej Rady Biegłych Rewidentów z dnia 16 lutego 2010 r. w sprawie krajowych standardów rewizji finansowej.

Schruff, W. (2013), Rewizja finansowa i sprawozdania finansowe, Accountancy, No. 5, pp. 21-24.

The Accountants Association in Poland (2011), Polityka badania sprawozdań finansowych: lekcje wyciagnięte z kryzysu, Accountancy, No. 2, pp. 35-37.

The Act from 19 August 2011 o redukcji niektórych obowiązków obywateli i przedsiębiorców (Dz. U. 2011, No. 232, item. 1378).

The Act from 29 September 1994 o rachunkowości, (Dz. U. 2013, item. 330).

The Act from 7 May 2009 o biegłych rewidentach i ich samorządzie, podmiotach uprawnionych do badania sprawozdań finansowych oraz o nadzorze publicznym (Dz. U. 2009, No. 77, item. 649) 
Walińska, E., Gad, J. (2012), Odpowiedzialność rad nadzorczych za sprawozdania finansowe - doświadczenia polskich spótek publicznych, Theoretical Journal of Accounting, Vol. 66 (122), The Accountants Association in Poland, Warszawa, pp. 20-21.

www.ifac.org/ (referred on 20/02/2014).

www.kibr.bip.waw.pl/index.php?k=S:m/1482/1 (referred on 30/12/2013).

Zmiany w ustawie o rachunkowości, Theoretical Journal of Accounting, No. 20 (308) 2011, p. 6. 